The following document is a pre-print version of:

Ross P-S, Bourke A (2017) High-resolution gamma ray attenuation density measurements on mining exploration drill cores, including cut cores. J. Apl. Geophys. 136:262-268

\title{
High-resolution gamma ray attenuation density measurements on mining exploration drill cores, including cut cores
}

\author{
Ross, P.-S.*, Bourke, A. \\ Institut national de la recherche scientifique, centre Eau Terre Environnement, 490, rue de la Couronne, Québec (QC), G1K \\ 9A9, Canada \\ * Corresponding author, rossps@ete.inrs.ca
}

\begin{abstract}
Physical property measurements are increasingly important in mining exploration. For density determinations on rocks, one method applicable on exploration drill cores relies on gamma ray attenuation. This non-

destructive method is ideal because each measurement takes only ten seconds, making it suitable for highresolution logging. However calibration has been problematic. In this paper we present new empirical, sitespecific correction equations for whole NQ and BQ cores. The corrections force back the gamma densities to the "true" values established by the immersion method. For the NQ core caliber, the density range extends to high values (massive pyrite, $\sim 5 \mathrm{~g} / \mathrm{cm}^{3}$ ) and the correction is thought to be very robust. We also present additional empirical correction factors for cut cores which take into account the missing material. These "cut core correction factors", which are not site-specific, were established by making gamma density measurements on truncated aluminum cylinders of various residual thicknesses. Finally we show two examples of application for the Abitibi Greenstone Belt in Canada. The gamma ray attenuation measurement system is part of a multi-sensor core logger which also determines magnetic susceptibility, geochemistry and mineralogy on rock cores, and performs line-scan imaging.
\end{abstract}

\section{Highlights}

- Physical property measurements are increasingly important in mining exploration

- Density can be measured on exploration drill cores using gamma ray attenuation

- New correction methods are presented to eliminate systematic errors

- Examples from the Abitibi Greenstone Belt are shown

\section{Keywords}

Density; rocks; core logging; mining exploration; gamma ray attenuation; sulfides

\section{Introduction}

Physical property measurements of rocks, such as magnetic susceptibility and density, are gaining importance in mining exploration. First, there is a growing recognition of the value of integrating physical property data and potential field surveys. This can be done through constrained geophysical inversions (e.g., Boszczuk et al., 2011; Spicer et al., 2011; Shamsipour et al., 2011, 2012; Tavakoli et al., 2012), or in preparing mineral prospectivity maps (e.g., Hayward et al., 2013). Second, physical property data are also needed to generate predictive geophysical exploration models for specific types of ore deposits (e.g., Clark, 2014). Third, these data can be integrated with geochemical and mineralogical data to give constrains on the origin of some ore deposits (e.g. Chu et al., 2015) or help discriminate between different lithologies, study hydrothermal alteration and contribute to a better understanding of the geological setting of ore deposits (e.g., Ross et al., 2013, 2016; Fresia et al., 2017).

Rock cores from exploration diamond drilling are ideal materials to perform physical property measurements on, because they give access to the third dimension, depth. Density determinations, the topic of this paper, can be performed with gamma-gamma tools lowered within the drill hole, but working on the cores may yield better results if the density of the rock itself is of interest, because of the effect of water and fractures on wireline logs. Also, wireline logging is not always possible.

In mining exploration and resource assessment, the traditional density measurement method for rock cores is the immersion technique, also known as hydrostatic weighing. This is relatively slow (minutes per sample for 
the "dry" density version suitable for non-porous rocks ${ }^{1}$ ) and is impractical for high-resolution logging of entire drill holes. In contrast, attenuation of gamma rays is a much quicker non-destructive method to measure the density of rock cores or sediment cores (Evans, 1965; Geotek Ltd., 2010). This technique is very common in scientific drilling (e.g., Weber et al., 1997; Best and Gunn, 1999; St-Onge et al., 2007; Tamura et al., 2015), not but in mining exploration. In summary, a radioactive source (which uses at least 100 times less ${ }^{137} \mathrm{Cs}$ than wireline tools ${ }^{2}$ ) produces a narrow beam of gamma rays that crosses the rock core and the non-attenuated portion is detected on the other side. From the gamma detector count rate and the measured core diameter, the rock density can be deduced, based on a calibration and a number of assumptions, as explained below.

Although the method is reasonably precise, calibration has been problematic for rocks, especially for cut cores and high-density rocks. In this paper, we report improvements on (1) calibration for whole cores for a wide range of densities including massive sulfides; and (2) how to better correct measurements on cut cores using an empirical approach. We also present applications of these corrected measurements in the Abitibi Greenstone Belt of Canada.

\section{Background: density measurements with the MSCL}

2.1 The multi-sensor core logger

In the current study, the core moves on a track within a multi-sensor core logger (MSCL), which can also measure the magnetic susceptibility of the core, quantify several chemical elements by energy-dispersive X-ray

fluorescence, and characterize mineralogical assemblages by visible light and near infrared spectrometry (Ross et al., 2013, 2014a, 2014b, 2016; Bourke et Ross, 2016). The logger, which is contained in a mobile laboratory, can also acquire a high-quality continuous image of the core using a line-scan camera. The MSCL at Institut national de la recherche scientifique in Quebec City, Canada, was designed, built and installed by Geotek Ltd. of Daventry, England, using sensors and scientific instruments manufactured by this company and other suppliers.

Typical core storage boxes in Canada contain four (BQ size) or three (NQ size) core sections, each measuring about $1.5 \mathrm{~m}$ in length. BQ core has a nominal diameter of $3.65 \mathrm{~cm}$ whereas NQ core has a nominal diameter of $4.76 \mathrm{~cm}$; these are very commonly used diamond drilling calibers in Canada and other countries. The core from each box is transferred into $1.55 \mathrm{~m}$-long core boats which travel in queue on the track. The core stops within or under each device during the time required to make a measurement

\footnotetext{
${ }^{1}$ The "wet" immersion density measurement, for porous rocks, requires water-saturation of the sample.

${ }^{2}$ Evans et al. (2012) mention that the gamma-gamma density (GGD) tool requires at least $40 \mathrm{GBq}$ of ${ }^{137} \mathrm{Cs}$ (i.e. 1.08 curies) whereas the MSCL source contains 0.01 curies.
}

(e.g., $\sim 1 \mathrm{~s}$ for magnetic susceptibility, $10 \mathrm{~s}$ for gamma density).

\subsection{Gamma density measurements}

The general method to make density measurements on rock cores using gamma ray attenuation with a MSCL has been previously discussed by Vatandoost et al. (2008) and Ross et al. (2013). The gamma source, the gamma detector, and the aluminum calibration piece required for the density measurements were supplied by Geotek Ltd. To own and operate such a radioactive source in Canada, a license from the Canadian Nuclear Safety Commission is required, and dosimetry devices must be worn by operators. However, dose rates are "only marginally above background" (Vatandoost et al., 2008).

Ross et al. (2013) show that the $1 \sigma$ precision of $10 \mathrm{~s}$ gamma density measurements with a $5 \mathrm{~mm}$ collimator is slightly better than $0.01 \mathrm{~g} / \mathrm{cm}^{3}$, or a $0.4 \%$ relative standard deviation (RSD), on aluminum. So accuracy, not precision, is the main issue with this method. Two measurements are needed to calculate rock density: the counts per second (cps) from the gamma detector, measured on every site of interest along the core, and the core thickness, measured once per core box with a vernier caliper (Ross et al., 2013). The cps values and core thicknesses are converted to what Vatandoost et al. (2008) called an aluminum bulk density and what Ross et al. (2013) called an uncorrected rock density, $\rho_{\text {uncorr. }}$ This is done using a calibration curve based on a machined aluminum calibration piece with cylindrical sections of different diameters, as explained by Best and Gunn (1999), Vatandoost et al. (2008), Geotek Ltd. (2010) and Ross et al. (2013). The maximum diameter of the calibration piece corresponds exactly to the nominal drill core diameter (here, NQ or BQ), so that the geometry is the same during calibration and routine measurements. This calibration, recommended by the MSCL's supplier, is performed two to three times a day during routine logging, to account for detector drift. The calibration method implicitly assumes that the rocks under study have the same atomic number/atomic mass $(\mathrm{Z} / \mathrm{A})$ values than aluminum. In practice, we obtain uncorrected gamma densities that are higher than immersion densities on the same samples, i.e. there is a systematic error.

\subsection{Sources of systematic error}

The calibration method is imperfect for several reasons. First, in the Abitibi Greenstone Belt of Canada for example, most rock samples have densities larger than that of aluminum i.e. $\sim 2.7 \mathrm{~g} / \mathrm{cm}^{3}$ (e.g., Boszczuk et al., 2011 reports a range from 2.5 to $3.1 \mathrm{~g} / \mathrm{cm}^{3}$ for the Matagami area), which means that one is commonly extrapolating well beyond the limits of the calibration curve. Second, the smallest segments of the aluminum calibration pieces may be narrower than the gamma beam (or at least the aluminum cylinder may not fully contain the beam). Third, rocks have $\mathrm{Z} / \mathrm{A}$ values and Compton attenuation 
coefficients that are different than those of aluminum, and this also causes systematic errors (Table 1).

\subsection{Removing the systematic error}

The way to overcome the systematic error on gamma densities is to measure numerous core samples with both the immersion method and the MSCL. The results are then plotted (immersion density versus $\rho_{\text {uncorr }}$ ) and a linear regression is calculated: the equation converts $\rho_{\text {uncorr }}$ into the corrected gamma density, $\rho_{\text {corr }}$. Ross et al. (2013) presented such a plot for non-mineralized, sulfide-poor whole NQ cores based on 103 Matagami samples and a density range of $2.8-3.2 \mathrm{~g} / \mathrm{cm}^{3}$ (uncorrected gamma densities). We expand this work here to sulfide-rich NQ cores and to BQ cores.

\subsection{Immersion densities}

The core samples used in the correction curves for gamma densities were weighted in air and water and their density was computed, knowing the water temperature. For this we used a Denver Instrument S6002 precision balance with a manufacturer-reported precision of $0.01 \mathrm{~g}$ and a capacity of $6 \mathrm{~kg}$. We tested the balance regularly with a $5 \mathrm{~kg}$ Troemner class 3 certified precision weight, and the accuracy was always better than $0.005 \%$. The precision of immersion densities, as determined by the relative standard deviation of a series 31 repeat measurements on single samples, ranges from $0.08 \%$ for a $4.5 \mathrm{~cm}$-long piece of BQ core weighting $119.21 \mathrm{~g}$ (average density $2.772 \pm 0.002 \mathrm{~g} / \mathrm{cm}^{3}$ ) to $0.016 \%$ for a $21 \mathrm{~cm}$-long piece of NQ core weighting $1012.94 \mathrm{~g}$ (average density $2.754 \pm 0.000 \mathrm{~g} / \mathrm{cm}^{3}$ ). These errors were deemed negligible for our purposes and we have treated the immersion densities as "true" values with which to compare the gamma densities from the MSCL.

\section{New correction for whole NQ cores}

Here we expand the correction equation for whole NQ cores up to $\sim 5 \mathrm{~g} / \mathrm{cm}^{3}$, including sulfide-rich rocks, from the Matagami and Chibougamau districts of the Abitibi Greenstone Belt. This makes the correction more widely applicable in the context of mineral exploration. For each of the 267 samples, several uncorrected gamma densities were measured with the MSCL (e.g., every 1-2 cm). The $\rho_{\text {uncorr }}$ data was averaged for each piece of core to allow a direct comparison with the immersion densities. The samples utilized include:

- The previously reported 103 sulfide-poor volcanic and intrusive, mafic to felsic samples from drill hole BRC-08-72 in the Matagami district (immersion densities between 2.70 and $3.09 \mathrm{~g} / \mathrm{cm}^{3}$, average of $2.89 \mathrm{~g} / \mathrm{cm}^{3}$ );

- 31 sulfide-poor volcanic and intrusive samples from drill holes LEM-15 and LEM-18 in the Lemoine sector of the Chibougamau district (immersion densities between 2.68 and $2.95 \mathrm{~g} / \mathrm{cm}^{3}$, average of $2.75 \mathrm{~g} / \mathrm{cm}^{3}$ given the large proportion of rhyolites);
- 133 sulfide-poor to sulfide-rich mafic to ultramafic samples from drill hole LN-12-15 near Lake Taché in the Chibougamau district (immersion densities between 2.77 and $5.01 \mathrm{~g} / \mathrm{cm}^{3}$, average of $\left.3.19 \mathrm{~g} / \mathrm{cm}^{3}\right)$. The sulfides are mostly pyrite and pyrrhotite (ranging up to massive sulfides), with minor chalcopyrite and trace sphalerite. Assays of the sampled intervals yielded $9-38 \% \mathrm{Fe}, 0.01-0.96 \% \mathrm{Cu}$ and $0-0.07 \%$ $\mathrm{Zn}$ over m-long core lengths.

The new equation to correct the gamma densities on whole NQ cores is (Fig. 1):

$$
\rho_{\text {corr }}=1.003 \rho_{\text {uncorr }}-0.1002
$$

This has the net effect of reducing the gamma densities by $0.09 \mathrm{~g} / \mathrm{cm}^{3}$ regardless of the density and the correction is valid for $\rho_{\text {uncorr }}$ between 2.75 and $5.00 \mathrm{~g} / \mathrm{cm}^{3}$. Because there is no obvious kink on figure 1 and since the coefficient of determination $\left(\mathrm{R}^{2}\right)$ is very high, it is not necessary to explicitly take into account the rock composition when correcting gamma densities, for the range of samples studied here. However, because our denser samples were sulfide-rich but not heavily mineralized, it would be important in the future to do further testing on rocks containing several percent $\mathrm{Cu}, \mathrm{Zn}$, $\mathrm{Pb}$ or $\mathrm{Ni}$ to see if the same relationship holds (cf. Mwenifumbo et al., 2005). However uncut cores with high metal grades are difficult to find.

We do not have a separate (independent) set of NQ whole core samples, on which the immersion and gamma densities are known, to test our correction on. But to check whether the correction is sensitive to the specific choice of samples utilized in obtained it, we randomly removed half the samples from the utilized set. The resulting linear regression was slightly different:

$$
\rho_{\text {corr }}=0.9995 \rho_{\text {uncorr }}-0.0899
$$

but again the net effect of the correction was to reduce all gamma densities by $0.09 \mathrm{~g} / \mathrm{cm}^{3}$. We conclude that we have used enough samples to obtain a robust correction.

\section{New correction for whole $B Q$ cores}

For $\mathrm{BQ}$ cores we present a new density correction equation based on 55 sulfide-poor, mafic to felsic, volcanic and intrusive samples from the Lemoine sector of the Chibougamau district. Drill holes used were LEM-34, LEM-36, LEM-40, LEM-44, LEM59, and LEM-59E. Immersion densities varied from 2.67 to $3.09 \mathrm{~g} / \mathrm{cm}^{3}$ (average of $2.83 \mathrm{~g} / \mathrm{cm}^{3}$ ). The linear regression on the plot of immersion densities vs. $\rho_{\text {uncorr }}$ gives the correction for whole BQ cores (Fig. 2a):

$$
\rho_{\text {corr }}=1.0943 \rho_{\text {uncorr }}-0.3554 \quad \text { (Eq. 3) }
$$


This correction is valid for $\rho_{\text {uncorr }}$ between 2.75 and $3.15 \mathrm{~g} / \mathrm{cm}^{3}$ only, for sulfide-poor samples. The net effect is to subtract $0.10 \mathrm{~g} / \mathrm{cm}^{3}$ from a $\rho_{\text {uncorr }}$ of $2.75 \mathrm{~g} / \mathrm{cm}^{3}$ and to subtract $0.06 \mathrm{~g} / \mathrm{cm}^{3}$ from a $\rho_{\text {uncorr }}$ of $3.15 \mathrm{~g} / \mathrm{cm}^{3}$.

We have tested this correction on $19 \mathrm{BQ}$ whole core samples from the Hébécourt area of the Blake River Group near Rouyn-Noranda, Québec, also in the Abitibi Greenstone Belt. These non-mineralized, mafic to felsic, volcanic and subvolcanic samples are not part of the dataset used in figure $2 a$ to obtain equation 3 . Figure $2 b$ shows the gamma densities before and after the correction. The corrected values correspond much better, as a whole, to the immersion densities.

\section{Additional corrections for cut cores}

Drill cores are commonly cut approximately in half by exploration companies (using a diamond blade) for assay purposes, so that in many core boxes, only cut cores are left. The missing material needs to be taken into account when calculating the gamma density. Ross et al. (2013) used an approximate correction, $d / t$, where $d$ is the nominal core diameter and $t$ is the residual core thickness measured with a vernier caliper. For example, for a perfect half core, $\mathrm{d} / \mathrm{t}=2$ so the uncorrected gamma density must be doubled to compensate for the missing thickness. This assumes that the gamma beam consists of a line crossing an object of constant thickness, when in fact the beam is a cone crossing a truncated cylinder.

Here we present a more accurate empirical method to correct gamma densities for the missing material in cut cores. We machined several $4 \mathrm{~cm}$-long NQ- and BQ-sized aluminum cylinders and then cut them lengthwise to simulate cut cores of various thicknesses. For example, for the NQ caliber, we produced cut aluminum cylinders with the following residual thicknesses: $4.76 \mathrm{~cm}$ (uncut), $3.58 \mathrm{~cm}, 3.13 \mathrm{~cm}, 2.42 \mathrm{~cm}, 2.20 \mathrm{~cm}, 1.48 \mathrm{~cm}$, and $1.03 \mathrm{~cm}$ (Fig. 3a). We then measured the apparent gamma density in the center of each piece over a long integration time $(120 \mathrm{~s})$. To calculate the apparent gamma density, the usual calibration curve was used: for example, the NQ cylinder cut to $3.58 \mathrm{~cm}$ has an apparent density of $2.06 \mathrm{~g} / \mathrm{cm}^{3}$, lower than that of aluminum, $2.71 \mathrm{~g} / \mathrm{cm}^{3}$, because of the missing material. A cut core correction factor $(\mathrm{CCCF})$ can then be calculated for each piece by dividing the aluminum density by the apparent gamma density; for our $3.58 \mathrm{~cm}$-thick piece this correction factor is 1.32. A plot of the CCCF vs. the residual core thickness (t) is then produced (Fig. 3b). A power-law regression yields the following equations with coefficients of determination $\left(\mathrm{R}^{2}\right)$ near 1.00 :

$$
\begin{aligned}
& C C C F=4.1041 t^{-0.8861} \quad(\mathrm{NQ} \text { caliber }) \quad(\text { Eq. 4) } \\
& C C C F=3.0037 t^{-0.8253} \quad(\text { BQ caliber }) \quad(\text { Eq. 5) }
\end{aligned}
$$

The CCCFs obtained by this method are significantly different from the former ones. For example, a NQ core cut to $2.0 \mathrm{~cm}$ thick has a correction factor of 2.22 with the new empirical method, compared to 2.38 with the former $\mathrm{d} / \mathrm{t}$ method. If the true rock density of this hypothetical cut core sample is $2.70 \mathrm{~g} / \mathrm{cm}^{3}$, then the old correction method would have given $2.90 \mathrm{~g} / \mathrm{cm}^{3}$, a difference of $0.20 \mathrm{~g} / \mathrm{cm}^{3}$ or $7 \%$. Therefore, the new correction method represents a major improvement in the density measurement of cut cores.

The fact that the cut cylinders used to establish the empirical CCCFs are made of aluminum, not rock, should not dramatically influence the results, despite the difference in $\mathrm{Z} / \mathrm{A}$ values between aluminum and rocks (Table 1). However, future tests will need to verify this assumption using a large number of rock core samples of different compositions, with the gamma density determined before and after cutting the core samples.

\section{Application}

We show the corrected and uncorrected gamma density for two NQ drill holes, LEM-18 in the Lemoine area, and LN12-15 drilled near Lake Taché, both in the Chibougamau region (Figs. 4-7). To take into account the mineralogical heterogeneity of the rock at small scale, we typically smooth the gamma density data with three-point or fivepoint moving averages. These two drill holes are also part of the dataset utilized in establishing the correction for whole NQ cores (eq. 1), so the good fit between the immersion densities and the corrected gamma densities on figures 4 and 6 might be attributed to circular logic. However, as explained above, the net effect of the density correction was the same when half of the calibration samples were randomly withheld (eq. 2). So to get rid of the circular logic, we could have calculated the corrected gamma densities with eq. 2 instead of eq. 1, and plotted only the immersion values not used in obtaining eq. 2 on figures 4 and 6 . This would have had no effect whatsoever on the corrected gamma densities, and would simply have removed about half the immersion data points from the figure.

\subsection{Lemoine}

The usefulness of correcting the gamma densities is quite clear for LEM-18, where the range of densities is relatively small (Fig. 4). Gamma densities are available for 2189 measurement points spread between the depths of $27.7 \mathrm{~m}$ and $689.0 \mathrm{~m}$, i.e. an average downcore resolution of $30 \mathrm{~cm}$. This drill hole is dominated by felsic volcanic to subvolcanic rocks (Marelle quartz feldspar porphyry, Alpha Rhyolite, Lemoine Rhyolite, hangingwall QFP, see Fig. 5), with some andesites and gabbros showing higher densities. There is no significant mineralization in this drill hole. Without the corrections, the gamma densities would be significantly offset relative to the immersion values (Fig. 4). 
Figure 5 plots the corrected gamma density versus the magnetic susceptibility for this hole, with the data points colored by lithology. It is interesting to note that the physical properties on their own allow some lithologies to be separated. The Marelle quartz feldspar porphyry, for example, occupies a distinct field, and so do the mafic dikes within the Alpha Rhyolite. Where there is overlap, geochemistry can be added for additional discriminating power (Ross et al., 2016; Fresia et al., 2017). For such an application, because the density range is small, it is important to use precise and accurate data.

\subsection{Lake Taché}

For LN-12-15, some 668 gamma density measurements were obtained between the depths of $13.0 \mathrm{~m}$ and $237.3 \mathrm{~m}$, i.e. an average downcore resolution of $34 \mathrm{~cm}$ (Fig. 6). The interval 13.0-66.2 $\mathrm{m}$ is interpreted to consist of the Archean Dore Lake Complex, a mafic to ultramafic layered intrusion known to host $\mathrm{Fe}-\mathrm{Ti}-\mathrm{V}$ ores in the region (Taner et al., 2000). The density peak at the bottom of this interval is caused by the abundance of magnetite (with trace iron sulfides) in the rock. The interval $66.2-231.0 \mathrm{~m}$ is interpreted as Archean volcanic and intrusive rocks ranging in composition from mafic to intermediate. The density variations in this interval are largely caused by the abundance of iron sulfides (pyrite and pyrrhotite, e.g., Fig. 7), ranging up to massive sulfides. Finally, at $231 \mathrm{~m}$, we enter a Proterozoic gabbro, which was not of interest, so that only the first six meters were logged.

The fit between corrected gamma densities and immersion densities for LN-12-15 is rather good (Fig. 6), considering that (i) the proportion of sulfides in the rock varies on $\mathrm{cm}-$, dm- and m-scales (e.g., Fig. 7c); (ii) the immersion densities are measured on core pieces a few $\mathrm{cm}$ - to a few dm-long, whereas the gamma densities involve a much smaller volume of rock and are made every $20-35 \mathrm{~cm}$.

\section{Discussion and conclusions}

Gamma ray attenuation is a method to measure rock or sediment density which is widely used in scientific drilling, but rarely in mining exploration, where the standard method is still immersion. Gamma densities are precise, but because the volume of analyzed material is much smaller than for the immersion method, the small scale mineralogical heterogeneity of the rocks creates somewhat noisy downhole profiles. Applying a moving average to high spatial resolution density data can alleviate this. The main quality issue for gamma densities is calibration, since a number of factors create systematic errors. In this paper, we have proposed empirical, sitespecific correction equations which force the gamma densities back to the "true" values established with the immersion method. We have presented such corrections for whole BQ and NQ cores using rocks from the Abitibi Greenstone Belt. In the case of NQ cores, the correction now extends to high-density, sulfide-rich rocks and include over 250 samples, making it very robust and widely applicable. For BQ cores, the density range is currently more limited and the number of samples remains smaller. Yet this BQ correction has been shown to work reasonably well when tested on an independent set of samples.

Cut cores present a special problem for density measurements with the gamma ray attenuation method. Again the solution is empirical, but fortunately not sitespecific. It simply consists of determining cut core correction factors on truncated aluminum cylinders; from this, a power-law regression gives the CCCF versus the residual core thickness equation for each caliber.

Finally, we have shown two examples of Abitibi Greenstone Belt drill cores logged with the gamma ray attenuation method, and with the relevant corrections applied. In the first drill hole, LEM-18, there is no mineralization but one application of interest is lithological discrimination within the volcanic and subvolcanic rocks, some of which are fine-grained and/or hydrothermally altered. Physical properties on their own, including the corrected gamma densities, allow some lithologies to be separated. Other lithologies have physical properties that overlap partly, but can be sorted out using geochemistry. Such an application requires precise and accurate density data.

The second drill hole, LN-12-15, contains zones of high density due to the presence of either magnetite or iron sulfides in the rocks. The density peaks stand out very well and in this case, for the simple purpose of locating the high-density zones in the drill hole, high quality data would not be needed. However, if gamma densities are ever to be used for mineral resource calculations, corrections such as those developed here will be essential.

\section{Acknowledgements}

The mobile laboratory was funded by an infrastructure grant from the Canadian Foundation for Innovation and the Government of Quebec. Logging in Matagami and Chibougamau was performed using research funding from ministère des Ressources Naturelles et de la Faune (Québec) and the Fonds québécois de recherche sur la nature et les technologies (FQRNT). Xstrata Zinc Canada (now Glencore plc), Cogitore Resources Inc. (now Yorbeau Resources), 2736-1179 Quebec Inc. and Chibougamau Diamond Drilling Ltd provided access to cores and logistical support. We thank all of these organizations and especially the following individuals: $\mathrm{M}$. Allard, M. Dessureault, S. Lacroix, C. Larouche, F. Lefebvre, S. Lépine, P. Pilote, G. Riverin, A. Roy and G. Roy. Some of the drill holes we studied were chosen in collaboration with the research sponsors; otherwise the sponsors had no role in study design, data collection/analysis/interpretation, or writing/submitting this article. Students who contributed to data acquisition include J. Arsenault, P.-G. Baron-Riopelle, A.-S. Corriveau, B. Fresia, P.H.T. Nguyen and T. Plamondon- 
Tremblay. The LogView software from the Geological Survey of Canada has been used to draft one figure.

\section{References}

Best, A.I. and Gunn, D.E., 1999. Calibration of marine sediment core loggers for quantitative acoustic impedance studies. Marine Geology, 160: 137-146.

Boszczuk, P. et al., 2011. A 3D gravity data interpretation of the Matagami mining camp, Abitibi Subprovince, Superior Province, Québec, Canada. Application to VMS deposit exploration. Journal of Applied Geophysics, 75: 77-86.

Bourke, A. and Ross, P.-S., 2016. Portable X-ray fluorescence measurements on exploration drill cores: comparing performance on unprepared cores and powders for "whole-rock" analysis. Geochemistry: Exploration, Environment, Analysis, 16: 147-157.

Chu, H., Chi, G., Bosman, S. and Card, C., 2015. Diagenetic and geochemical studies of sandstones from drill core DV10-001 in the Athabasca basin, Canada, and implications for uranium mineralization. Journal of Geochemical Exploration, 148: 206-230.

Clark, D.A., 2014. Magnetic effects of hydrothermal alteration in porphyry copper and iron-oxide copper-gold systems: A review. Tectonophysics, 624-625: 46-65.

Evans, H.B., 1965. GRAPE - A device for continuous determination of density and porosity, Proceedings of the 6th annual SPWLA logging symposium. Society of Professional Well Log Analysts, Dallas, Texas, pp. B1B25.

Evans, M. et al., 2012. Sourceless neutron-gamma gensity (SNGD): A radioisotope-free bulk density measurement: Physics principles, environmental effects, and applications, Proceedings - SPE Annual Technical Conference and Exhibition, pp. 2004-2021.

Fresia, B., Ross, P.-S., Gloaguen, E. and Bourke, A., 2017. Lithological discrimination based on statistical analysis of multi-sensor drill core logging data in the Matagami VMS district, Quebec, Canada. Ore Geology Reviews, 80: $552-563$.

Geotek Ltd., 2010. Multi-Sensor Core Logger (MSCL) Manual, version $05-10,176 \mathrm{pp}$. (downloaded from www.geotek.co.uk on 26 December 2010).

Hallenburg, J.K., 1984. Geophysical logging for mineral and engineering applications. PennWell Books, Tulsa, Oklahoma, $254 \mathrm{pp}$.

Hayward, N., Enkin, R.J., Corriveau, L., Montreuil, J.-F. and Kerswill, J., 2013. The application of rapid potential field methods for the targeting of IOCG mineralisation based on physical property data, Great Bear magmatic zone, Canada. Journal of Applied Geophysics, 94: 4258.

Mwenifumbo, C.J., Salisbury, M., Elliott, B.E. and Pflug, K.A., 2005. Use of multi-channel gamma-gamma logs to improve the accuracy of log-derived densities of massive sulfides. Petrophysics, 46: 346-353.
Ross, P.-S., Bourke, A. and Fresia, B., 2013. A multi-sensor logger for rock cores: Methodology and preliminary results from the Matagami mining camp, Canada. Ore Geology Reviews, 53: 93-111.

Ross, P.-S., Bourke, A. and Fresia, B., 2014a. Improving lithological discrimination in exploration drill-cores using portable $\mathrm{X}$-ray fluorescence measurements: (1) testing three Olympus Innov-X analysers on unprepared cores. Geochemistry: Exploration, Environment, Analysis, 14: 171-185.

Ross, P.-S., Bourke, A. and Fresia, B., 2014b. Improving lithological discrimination in exploration drill-cores using portable X-ray fluorescence measurements: (2) applications to the $\mathrm{Zn}-\mathrm{Cu}$ Matagami mining camp, Canada. Geochemistry: Exploration, Environment, Analysis, 14: 187-196.

Ross, P.-S., Bourke, A., Mercier-Langevin, P., Lépine, S., Leclerc, F. and Boulerice, A., 2016. High-resolution physical properties, geochemistry and alteration mineralogy for the host rocks of the Archean Lemoine auriferous VMS deposit, Canada. Economic Geology, 111: 561-1574.

Shamsipour, P., Marcotte, D., Chouteau, M. and Allard, M., 2011. Stochastic inversion of a gravity field on multiple scale parameters using surface and borehole data. Geophysical Prospecting, 59: 998-1012.

Shamsipour, P., Marcotte, D. and Chouteau, M., 2012. Integrating multiscale parameters information into 3D stochastic magnetic anomaly inversion. Geophysics, 77: D85-D93.

Spicer, B., Morris, B. and Ugalde, H., 2011. Structure of the Rambler Rhyolite, Baie Verte Peninsula, Newfoundland: Inversions using UBC-GIF Grav3D and Mag3D. Journal of Applied Geophysics, 75: 9-18.

St-Onge, G., Mulder, T., Francus, P., and Long, B., 2007. Continuous physical properties of cored marine sediments. Developments in Marine Geology, 1: 63-98.

Tamura, Y., Busby, C.J., Blum, P., and the Expedition 350 Scientists, 2015. Expedition 350 methods. Proceedings of the International Ocean Discovery Program, Expedition 350: Izu-Bonin-Mariana Rear Arc, p. 1-42

Taner, M.F., Gault, R.A., and Scott Ercit, T., 2000. Vanadium mineralization and its industry in Canada. The Gangue (GAC Mineral Deposits Division) 65: 1-9.

Tavakoli, S., Elming, S.-A. and Thunehed, H., 2012. Geophysical modelling of the central Skellefte district, Northern Sweden; an integrated model based on the electrical, potential field and petrophysical data. Journal of Applied Geophysics, 82: 84-100.

Vatandoost, A., Fullagar, P. and Roach, M., 2008. Automated multi-sensor petrophysical core logging. Exploration Geophysics, 39: 181-188.

Weber, M.E., Niessen, F., Kuhn, G., and Wiedicke, M., 1997. Calibration and application of marine sedimentary physical properties using a multi-sensor core logger. Marine Geology, 136: 151-172. 
Table 1. Density and atomic number/atomic mass (Z/A) values for selected igneous rocks, sedimentary rocks, hydrothermal alteration minerals, sulfides, oxides and aluminum, based on Hallenburg (1984).

\begin{tabular}{lcc}
\hline \multicolumn{1}{c}{ Substance } & Density $\left(\mathrm{g} / \mathrm{cm}^{3}\right)$ & Z/A \\
\hline Galena & 7.5 & 0.409 \\
Sphalerite & 4.0 & 0.472 \\
Chalcopyrite & 4.2 & 0.475 \\
Magnetite & 5.2 & 0.477 \\
Pyrrhotite & 4.6 & 0.481 \\
${ }^{* *}$ Aluminum ${ }^{* *}$ & 2.7 & 0.482 \\
Pyrite & 5.1 & 0.485 \\
Gabbro, average & 3.0 & 0.494 \\
Granite, average & 2.7 & 0.497 \\
Muscovite & 2.9 & 0.497 \\
Sandstone, average & 2.7 & 0.499 \\
Limestone, average & 2.7 & 0.500 \\
Chlorite & 2.7 & 0.506 \\
\hline
\end{tabular}

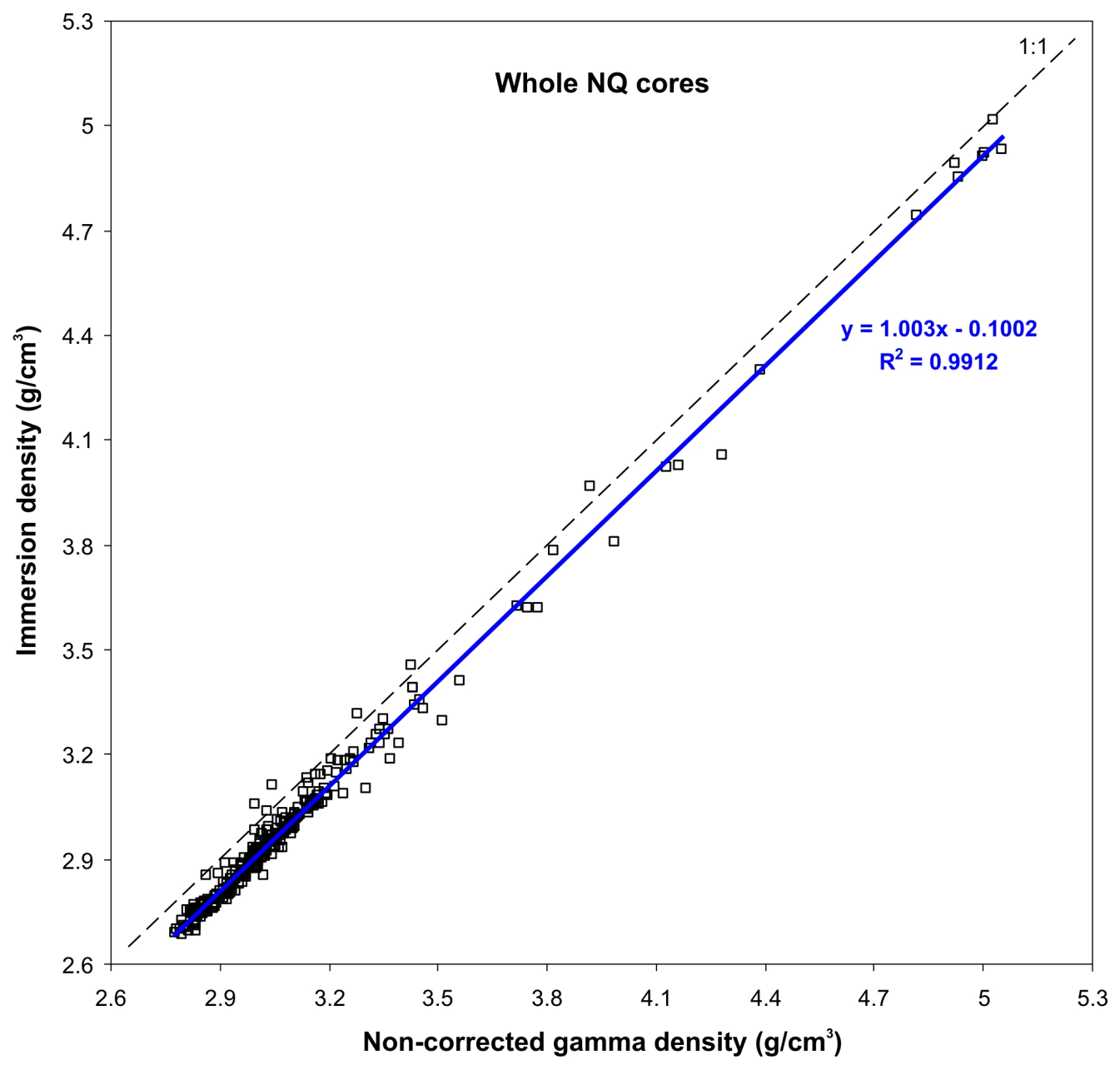

Fig. 1. Comparison between immersion densities $\left(\mathrm{g} / \mathrm{cm}^{3}\right)$ and the average of uncorrected gamma densities on the same samples $\left(\mathrm{g} / \mathrm{cm}^{3}\right)$ for 267 pieces of whole $\mathrm{NQ}$ core from the Abitibi Greenstone Belt. The thick blue line is a linear regression through the data and its equation can be used to correct the gamma densities. See text for discussion. 
a

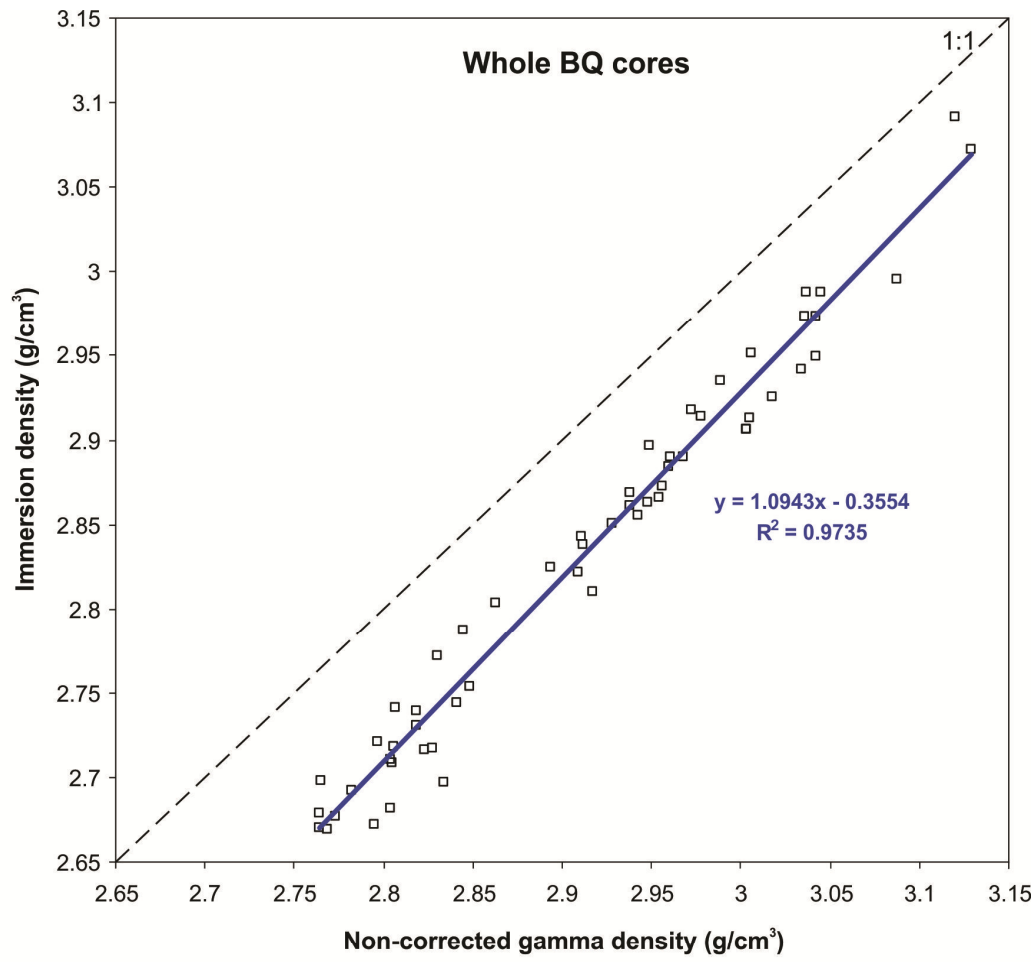

b

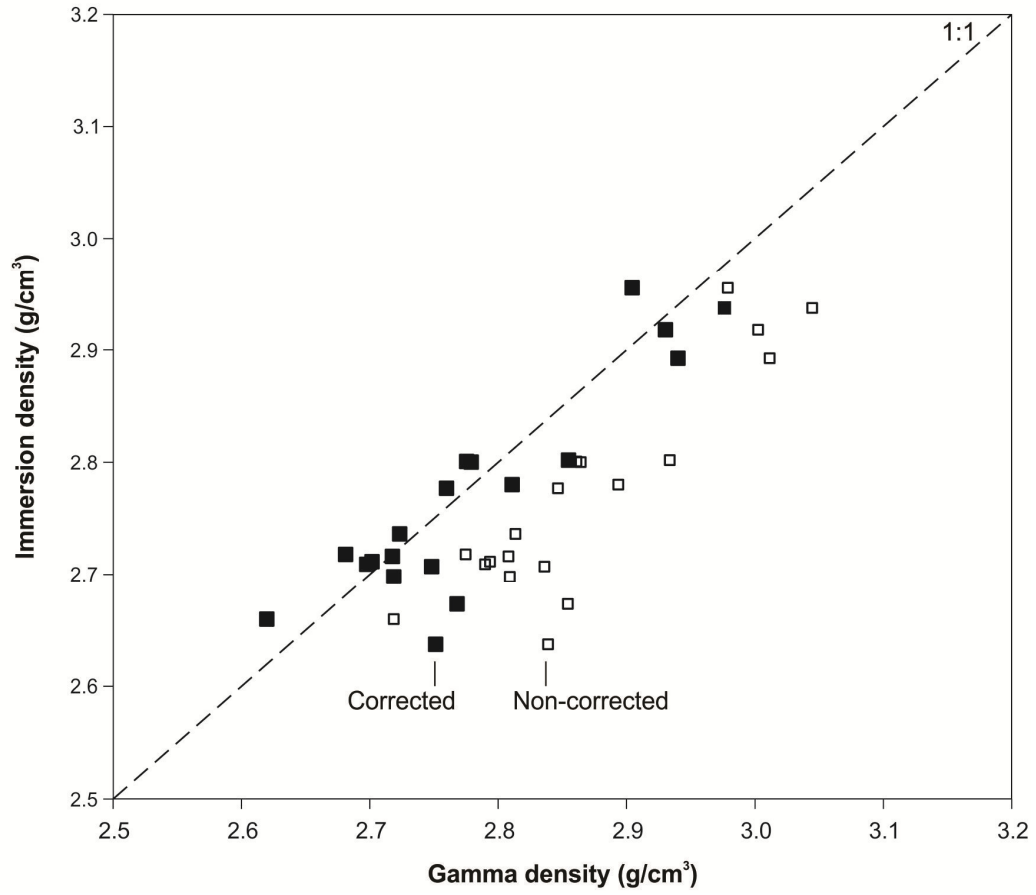

Fig. 2. (a) Comparison between immersion densities $\left(\mathrm{g} / \mathrm{cm}^{3}\right)$ and the average of uncorrected gamma densities on the same samples $\left(\mathrm{g} / \mathrm{cm}^{3}\right)$ for 55 pieces of whole $B Q$ core from the Lemoine sector. The thick blue line is a linear regression through the data and its equation can be used to correct the gamma densities (equation 3 ). See text for discussion. (b) Application of the correction to 19 pieces of whole BQ cores from the Hébécourt area, also in the Abitibi Greenstone Belt. 
a
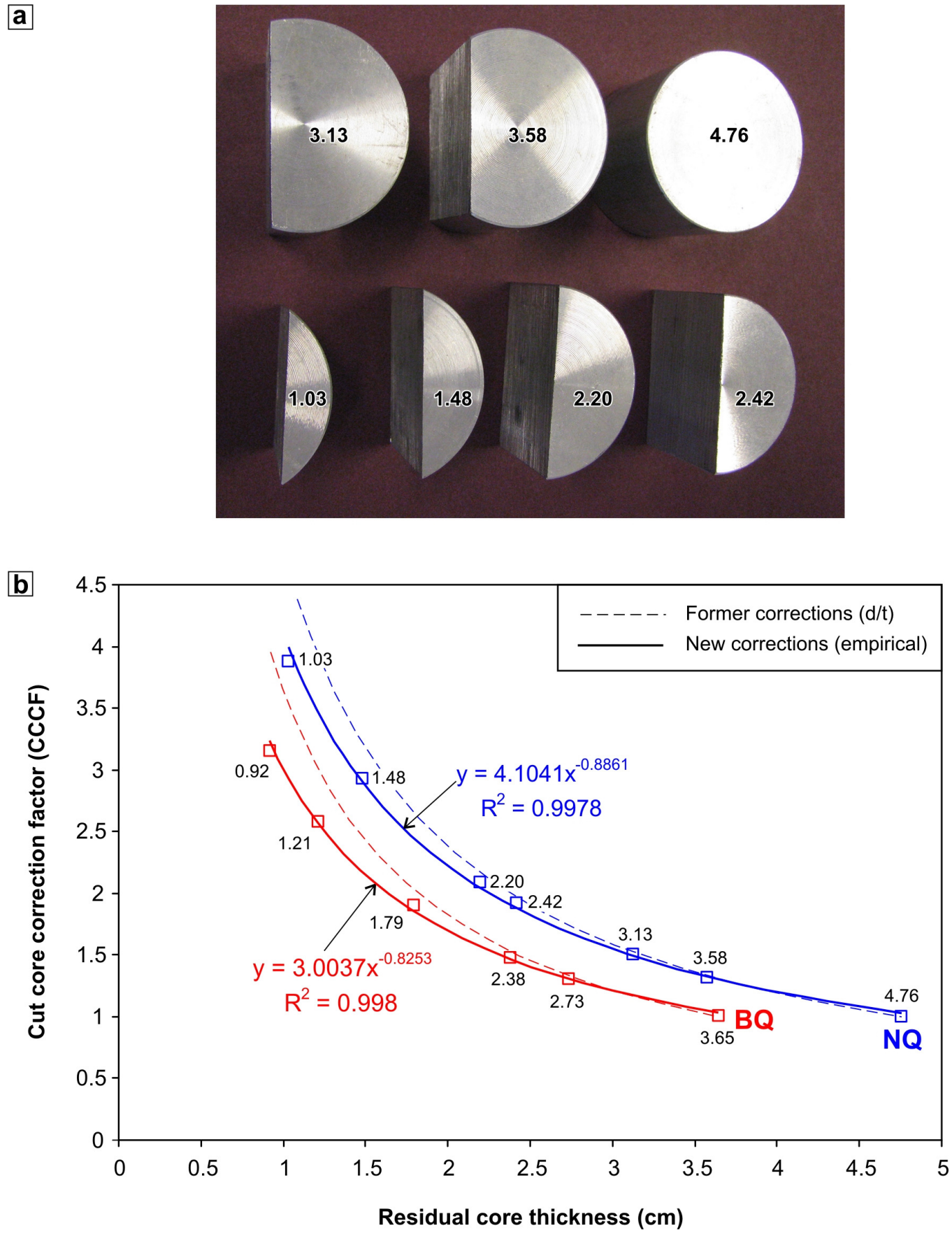

Fig. 3. Density corrections for cut cores. (a) Cut NQ-caliber aluminum cylinders used to establish the new empirical correction. The numbers on the cylinders are the residual thicknesses in $\mathrm{cm}$. (b) Cut core correction factors (CCCFs) as a function of the residual core thickness $(\mathrm{cm})$ for $B Q$ (red) and NQ (blue). The dashed lines show the former corrections and the continuous lines show the new empirical corrections. 


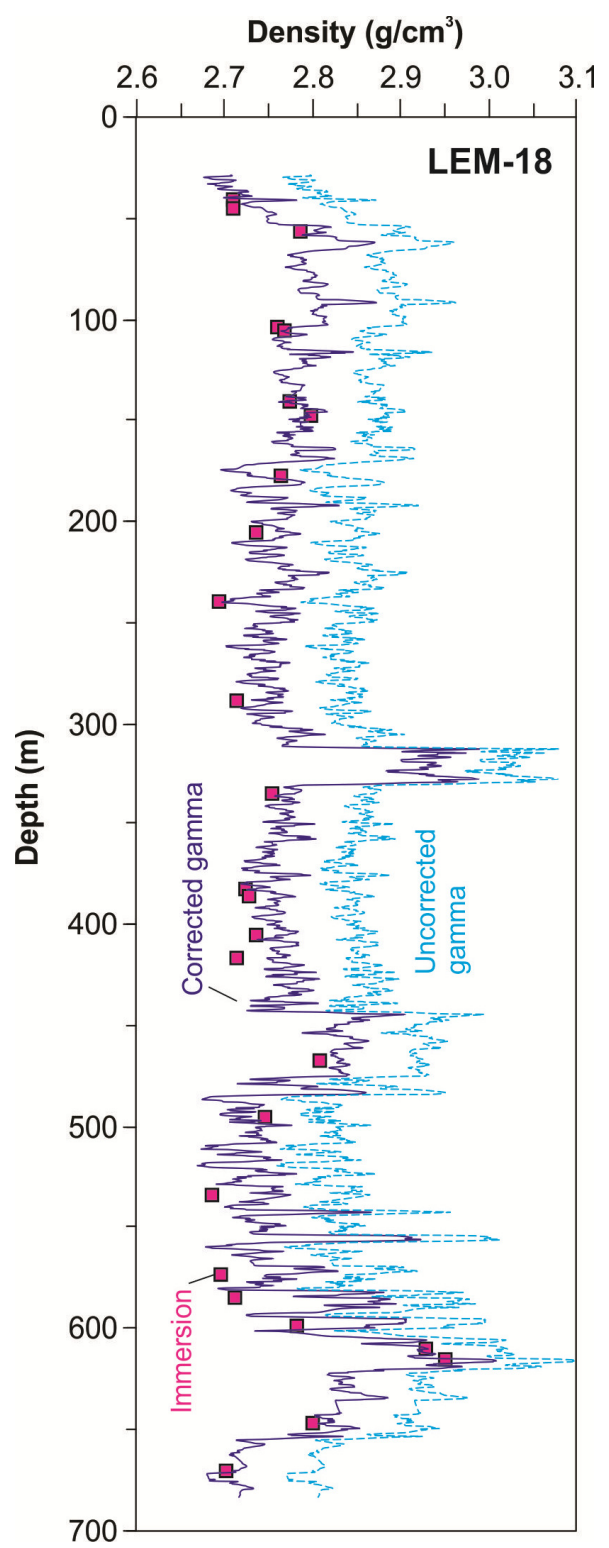

Fig. 4. Density versus depth in drill hole LEM-18 (NQ caliber) from the Chibougamau district, Abitibi Greenstone Belt. Both the corrected and uncorrected gamma density profiles use five point moving averages. The available immersion densities are plotted as pink squares for comparison. 


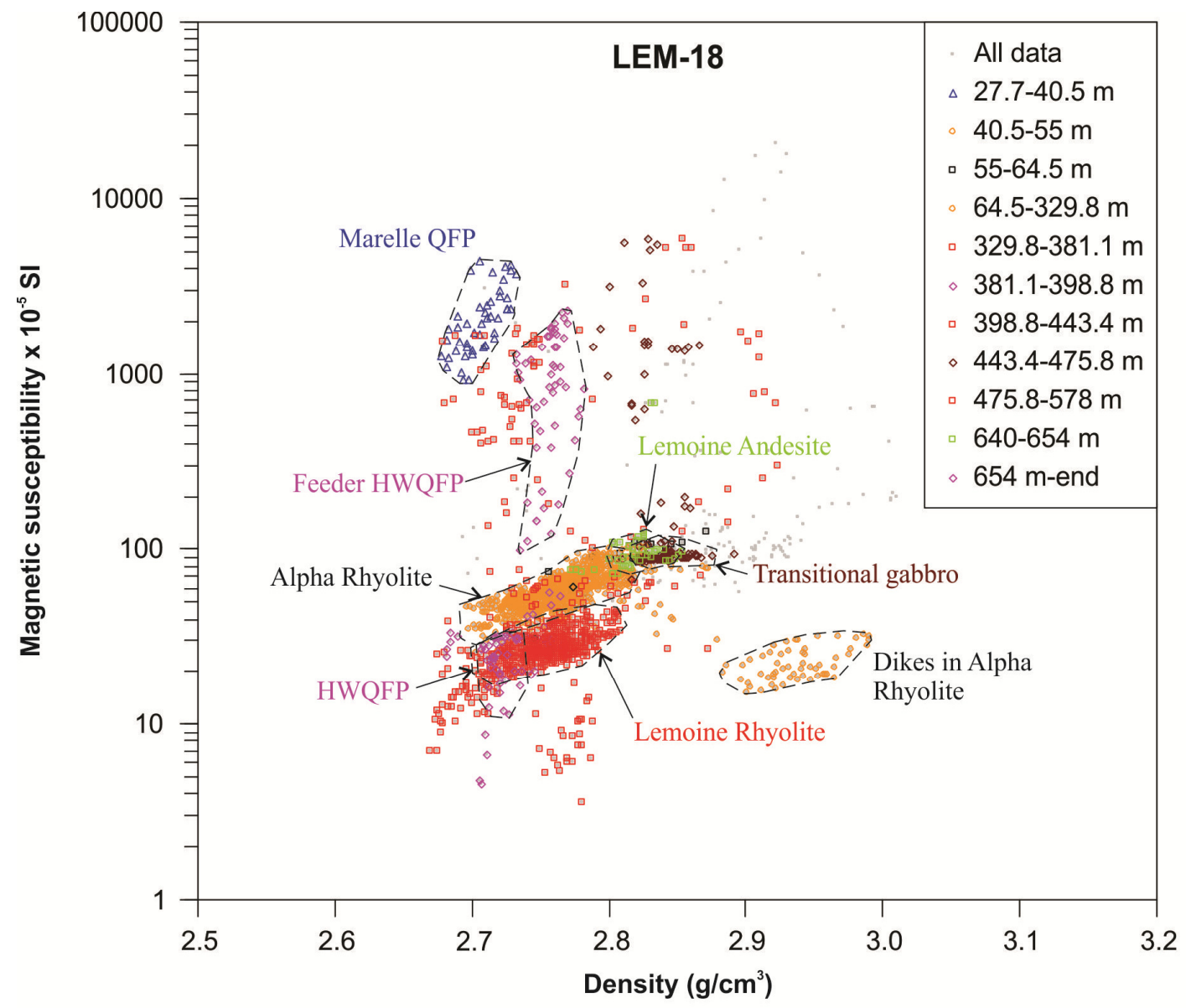

Fig. 5. Corrected gamma density versus magnetic susceptibility, colored by lithology, in drill hole LEM-18. A five point moving average has been applied. HWQFP means hangingwall QFP. See text for discussion. 


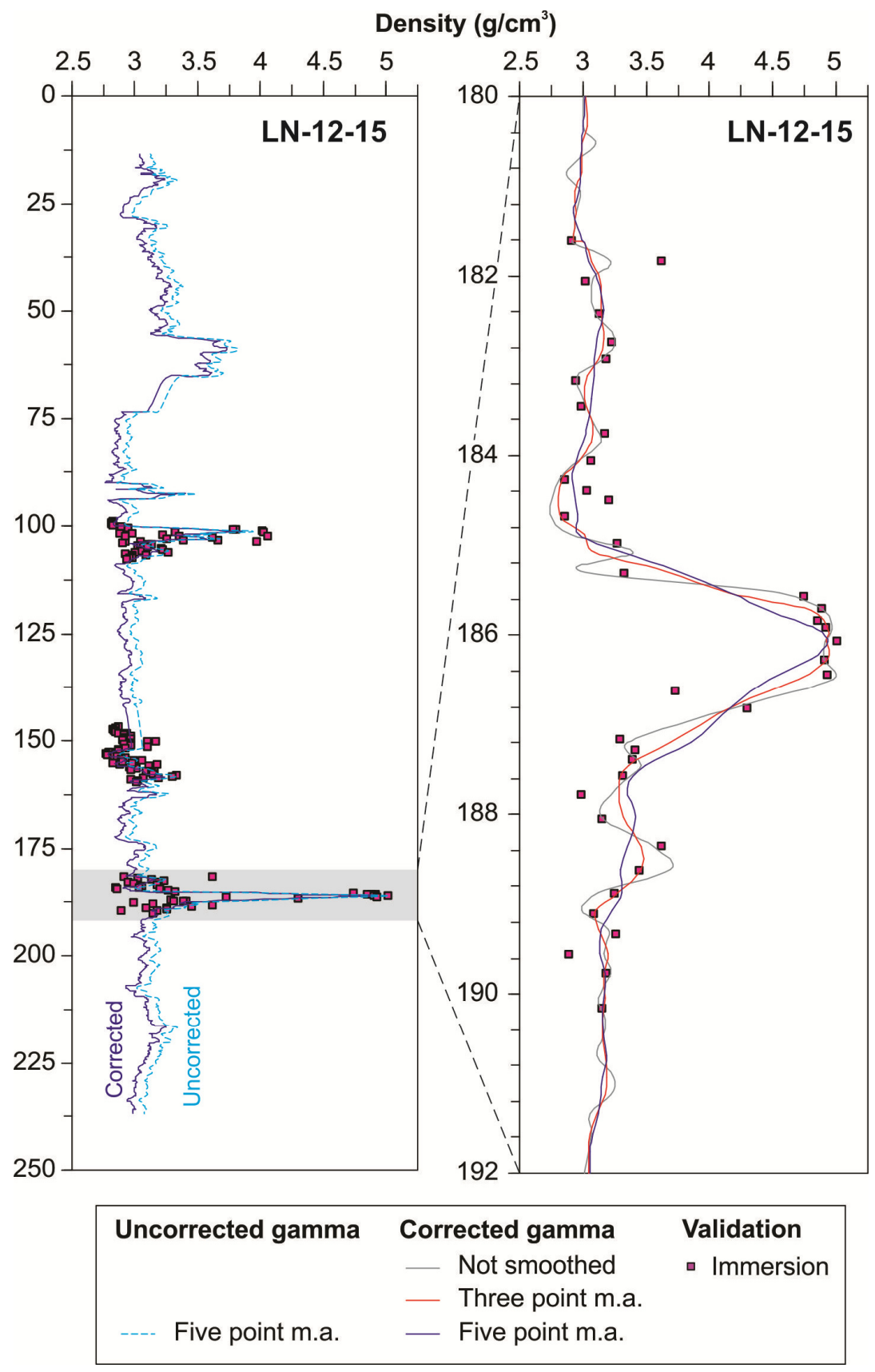

Fig. 6. Density versus depth in hole LN-12-15 (NQ caliber) from the Chibougamau district, Abitibi Greenstone Belt. The graph on the left shows the corrected and uncorrected gamma density logs using a five point moving average (m.a.). The close-up view on the right shows one sulfide-rich interval and the surrounding sulfide-poor rocks (unsmoothed corrected gamma density data; three-point m.a.; five point m.a.). The available immersion densities are plotted as pink squares for comparison. 


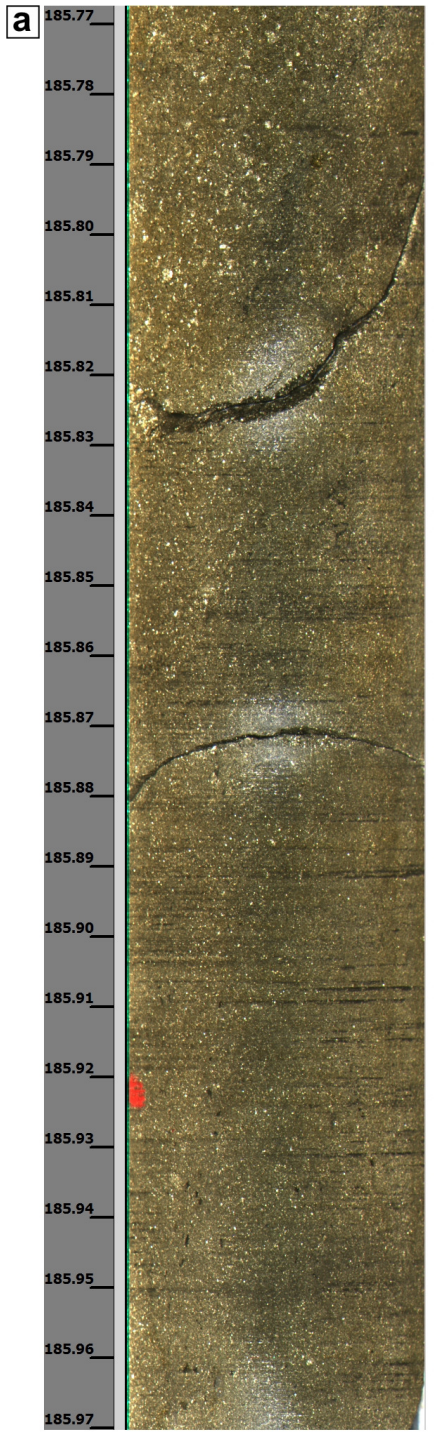

Density: $4.92 \mathrm{~g} / \mathrm{cm}^{3}$

$29 \% \mathrm{Fe}$

$>10 \%$ S

$0.48 \% \mathrm{Cu}$

$0.01 \% \mathrm{Zn}$

\section{b}

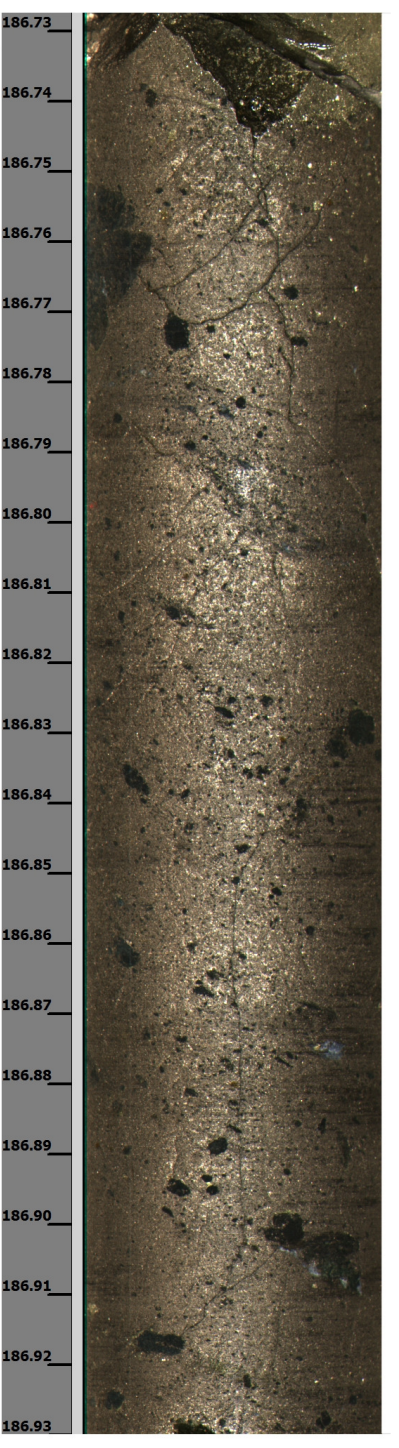

Density: $4.30 \mathrm{~g} / \mathrm{cm}^{3}$

$$
\begin{aligned}
& 38 \% \mathrm{Fe} \\
& >10 \% \mathrm{~S} \\
& 0.12 \% \mathrm{Cu} \\
& 0.02 \% \mathrm{Zn}
\end{aligned}
$$

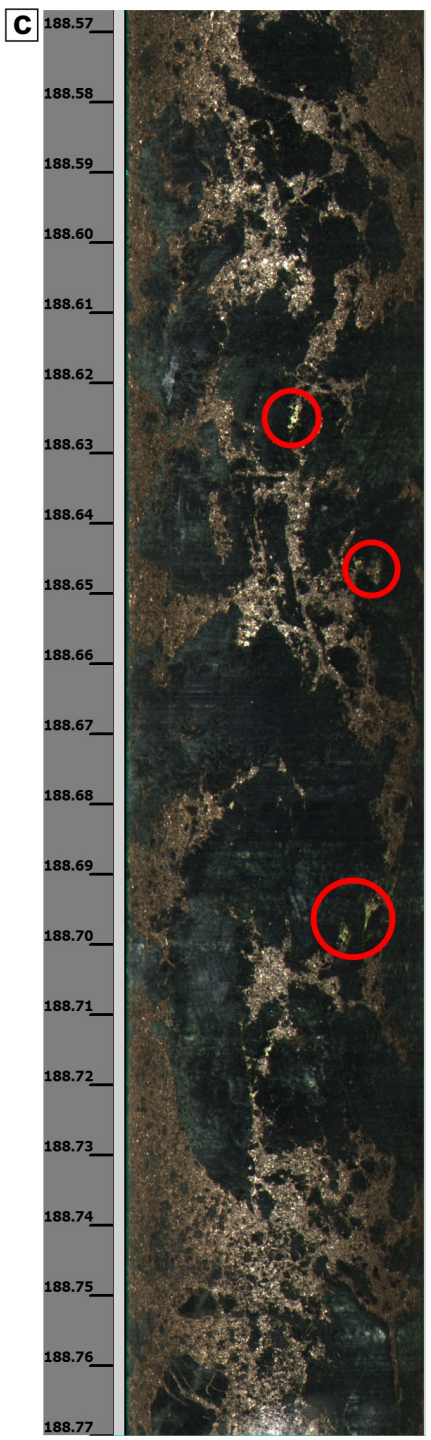

Density: $3.45 \mathrm{~g} / \mathrm{cm}^{3}$

$27 \% \mathrm{Fe}$

$8.2 \% \mathrm{~S}$

$0.96 \% \mathrm{Cu}$

$0.03 \% \mathrm{Zn}$

Fig. 7. Linescan images of three sulfide-rich whole cores from drill hole LN-12-15: (a) massive pyrite; (b) massive pyrrhotite; (c) semi-massive pyrrhotite with minor chalcopyrite (circled in red). Downhole depth is indicated in the left margins. Densities indicated at the bottom of the photos are immersion values for the following depths: (a) 185.88-185.97 m; (b) 186.73-187.00 m; (c) 188.50-188.77 m. Laboratory assay values (done on half cores cut after our density measurements had been made) are for the intervals (a) 185.3-185.9 m; (b) 185.9-187.1 m; (c) 188.4-189.4 m. 